\title{
Preparation and Evaluation of Bael-Mango Jam
}

\author{
Shafaly Sharma, Rakesh Gehlot, Rattan Singh", Rekha and Ritu Sindhu \\ Centre of Food Science and Technology, CCS Haryana Agricultural University, \\ Hisar-125 004, Haryana, India \\ *Corresponding author
}

\section{A B S T R A C T}

\section{Keywords}

Bael, Mango,

Blends, Jam,

Chemical, Sensory,

Parameters, Storage

Article Info

Accepted:

07 June 2019

Available Online:

10 July 2019
The bael-mango jam was prepared and evaluated for changes in chemical and sensory parameters at monthly intervals for three months storage period. Total soluble solids and acidity increased significantly, while total carotenoids decreased significantly in jam with the advancement in three months storage period. The colour and appearance, texture, taste, flavour, mouth feel and overall acceptability of bael-mango jam decreased significantly during three months storage duration, however, the products were found acceptable level even after three months storage. Jam prepared with 0 bael: 100 mango pulp ratio was found most acceptable.

\section{Introduction}

Bael (Aegle marmelos Correa.) is one of the important fruit trees of Indian origin and it has been known in India from pre-historic times. Its medicinal properties have been dealt with in 'Charak Samhita', an early medicinal treatise in Sanskrit. The pulp of fruit contains many functional and bioactive compounds such as carotenoids, phenolics, alkaloids, coumarins, flavonoids, terpenoids and other antioxidants, which may protect against chronic diseases. The fruit is aromatic, cooling and laxative. The ripe bael fruit is a tonic, restorative, laxative and is good for heart and brain, whereas mature bael fruit is astringent, digestive, stomachic. The fruit is used for the treatment of diarrhoea and dysentery. Bael fruit is not consumed as a table fruit due to its hard shell, mucilaginous pulp and a large number of seeds and fibres in its pulp, although, it has a great potential for processing into several products viz., ready-to-serve drink, nectar, squash, preserve, candy, cheese and toffee.

Mango (Magnifera indica) belongs to family Anacardiaceae. It is native to Indian subcontinent from where it spread all over the World. It is national fruit of India, Pakistan, Philippines and Bangladesh. It is considered as "The king of all fruits". Mango is generally sweet, although, the taste and texture of its flesh varies from soft pulpy to fibrous. Mango 
pulp contains phytochemicals and nutrients. It has been found to protect against colon, leukemia and prostate cancers. Mango pulp may be incorporated into ready-to-serve drink, nectar, squash, syrup, cheese, toffee, pickles, ice-cream and desserts.

Blending of pulp/juice from two or more fruits could be an economic requisite to utilize profitably some fruits for processing, which may not otherwise have favourable characteristics like colour, flavour, aroma, taste and mouthfeel. People have less preference for bael fruits due to its peculiar taste and flavour. However, blending of mango pulp with bael pulp may improve colour and appearance, taste, flavour, mouthfeel, texture, overall acceptability and nutrition of its blended products. Keeping all these aspects in view, the present research work was planned with the objectives to standardize an appropriate combination of Bael-Mango blends for preparation of jam and to evaluate the storage quality of blended products.

\section{Materials and Methods}

The present investigation was carried out in Centre of Food Science and Technology, CCS Haryana Agricultural University, Hisar during 2015-16. Uniformly ripe bael and mango fruits were procured from local market, Hisar. Bael fruits were washed thoroughly in running water and broken by striking against hard surface. The fruit pulp along with its seeds and fibres were scooped out with the help of a stainless steel spoon. An equal amount of water to the weight of pulp was mixed with the pulp. The mixture of pulp and water was kneaded, heated at $80^{\circ} \mathrm{C}$ and passed through fruit pulper to obtain homogeneous pulp free from seeds and fibres. Sodium benzoate @ 1 $\mathrm{g} / \mathrm{kg}$ pulp was mixed with the pulp. The pulp was then packed in polypropylene jars and stored in deep freezer.
Mango fruits were washed thoroughly in clean running water and peeled off. The pulp was separated from the stone with the help of a stainless steel knife and it was blended in a mixer to obtain fine pulp. Sodium benzoate @ $1 \mathrm{~g} / \mathrm{kg}$ pulp was mixed with the pulp. The pulp was then packed in polypropylene jars and stored in deep freezer.

The bael and mango pulp were blended in ratio of 100:0, 80:20, 60:40, 40:60, 20:80 and $0: 100$ ratio. On the basis of sensory evaluation, 60 Mango: 40 Bael pulp ratio was optimized for development and evaluation of the products.

For preparing jam, one $\mathrm{kg}$ blended pulp was cooked after mixing $700 \mathrm{~g}$ sugar, $5 \mathrm{~g}$ citric acid and $3 \mathrm{~g}$ pectin. Jam was filled hot in 150 g capacity sterilized glass bottles, screw capped properly, cooled in air, labelled and stored at room temperature for three months (Fig. 1).

Bael-Mango jam was analyzed for changes in chemical and sensory parameters at monthly intervals for three months. Total soluble solids (TSS) were estimated at ambient temperature by hand refractometer (58-92\%) for baelmango jam. Acidity was determined by method of Ranganna (2014). Total carotenoids were analyzed by Rodriguez-Amaya method (1999). The overall acceptability of baelmango jam was based on mean scores obtained for all the sensory characters i.e., colour and appearance, texture, taste, flavour and mouthfeel. The characters with mean scores of 6 and above out of 9 were considered acceptable (Ranganna, 2014).

The treatments were replicated thrice and the data were analyzed statistically using completely randomized design. The critical difference value at 5 per cent level was used for making comparison among different treatments during storage. 


\section{Results and Discussion}

The perusal of data (Table 1) reveals that there was a significant increase in total soluble solids (TSS) of bael-mango jam with the advancement in storage period.

The increase in TSS during storage might be due to acid hydrolysis of polysaccharides like pectin and starch. The results are in agreement with those of Safdar et al., (2012) in mango jam and Saravanan et al., (2004). Acidity also increased significantly in bael-mango jam during three months storage. This might be due to rise in concentration of weakly ionized acids by degradation of polysaccharides and oxidation of reducing sugars or by break down of pectic substances and uronic acid. Similar observations were reported by Wani et al., (2013) in karonda jam.

Table.1 Changes in chemical and sensory parameters of bael-mango jam during storage

\begin{tabular}{|c|c|c|c|c|c|c|c|c|c|c|}
\hline $\begin{array}{l}\text { Treatments* } \\
\text { Bael: } \\
\text { Mango }\end{array}$ & $\begin{array}{l}\text { Storage } \\
\text { period } \\
\text { (months) }\end{array}$ & $\begin{array}{c}\text { Total } \\
\text { soluble } \\
\text { solids } \\
(\%)\end{array}$ & $\begin{array}{l}\text { Acidit } \\
\text { y }(\%)\end{array}$ & $\begin{array}{c}\text { Total } \\
\text { carotenoid } \\
\text { s (mg/100 } \\
\text { g) }\end{array}$ & $\begin{array}{c}\text { Colour } \\
\text { and } \\
\text { appearanc } \\
\text { e (score } \\
\text { out of 9) }\end{array}$ & $\begin{array}{l}\text { Texture } \\
\text { (score } \\
\text { out of 9) }\end{array}$ & $\begin{array}{l}\text { Taste } \\
\text { (score } \\
\text { out of } \\
9 \text { ) }\end{array}$ & $\begin{array}{l}\text { Flavour } \\
\text { (score } \\
\text { out of } \\
9 \text { ) }\end{array}$ & $\begin{array}{c}\text { Mouth } \\
\text { feel } \\
\text { (score } \\
\text { out of 9) }\end{array}$ & $\begin{array}{c}\text { Overall } \\
\text { acceptabilit } \\
\text { y (score out } \\
\text { of } 9 \text { ) }\end{array}$ \\
\hline \multirow[t]{4}{*}{ 100:0 } & $\mathbf{0}$ & 68.00 & 0.65 & 1.02 & 8.00 & 8.10 & 7.40 & 8.00 & 7.80 & 7.87 \\
\hline & 1 & 68.67 & 0.72 & 0.97 & 7.80 & 8.00 & 7.50 & 7.60 & 7.70 & 7.72 \\
\hline & 2 & 68.73 & 0.76 & 0.91 & 7.30 & 7.50 & 7.10 & 7.20 & 7.40 & 7.30 \\
\hline & 3 & 70.00 & 0.78 & 0.86 & 7.20 & 6.90 & 7.10 & 6.80 & 7.10 & 7.00 \\
\hline \multirow[t]{4}{*}{$60: 40$} & $\mathbf{0}$ & 68.00 & 0.72 & 0.98 & 7.70 & 8.00 & 7.80 & 8.50 & 8.10 & 8.04 \\
\hline & 1 & 68.30 & 0.74 & 0.84 & 7.50 & 7.50 & 7.30 & 8.30 & 7.80 & 7.68 \\
\hline & 2 & 68.40 & 0.76 & 0.76 & 7.10 & 7.40 & 7.10 & 8.10 & 7.20 & 7.38 \\
\hline & 3 & 68.67 & 0.83 & 0.67 & 7.20 & 7.30 & 6.30 & 7.60 & 7.30 & 7.28 \\
\hline \multirow[t]{4}{*}{ 0:100 } & $\mathbf{0}$ & 68.00 & 0.74 & 0.92 & 8.20 & 8.60 & 8.30 & 8.20 & 8.40 & 8.34 \\
\hline & 1 & 68.47 & 0.76 & 0.88 & 8.00 & 8.10 & 8.10 & 8.10 & 8.10 & 8.08 \\
\hline & 2 & 68.53 & 0.78 & 0.84 & 7.90 & 7.80 & 7.80 & 7.80 & 7.90 & 7.86 \\
\hline & 3 & 68.67 & 0.81 & 0.78 & 7.60 & 7.50 & 7.70 & 7.40 & 7.80 & 7.58 \\
\hline \multirow[t]{2}{*}{ CD at $5 \%$} & $\begin{array}{r}\text { Treatmen } \\
\mathbf{t}\end{array}$ & 0.17 & NS & 0.08 & 0.38 & 0.33 & 0.46 & 0.32 & 0.36 & 0.15 \\
\hline & Storage & 0.20 & 0.05 & 0.09 & 0.43 & 0.38 & 0.54 & 0.38 & 0.42 & 0.17 \\
\hline \multicolumn{2}{|c|}{ Treatment x Storage } & 0.34 & NS & NS & NS & NS & NS & NS & NS & NS \\
\hline
\end{tabular}

*Recipe- $1 \mathrm{~kg}$ blended pulp, $700 \mathrm{~g}$ sugar, $5 \mathrm{~g}$ citric acid and $3 \mathrm{~g}$ pectin; NS - Non-significant 
Fig.1 Flow sheet for preparation of bael-mango jam

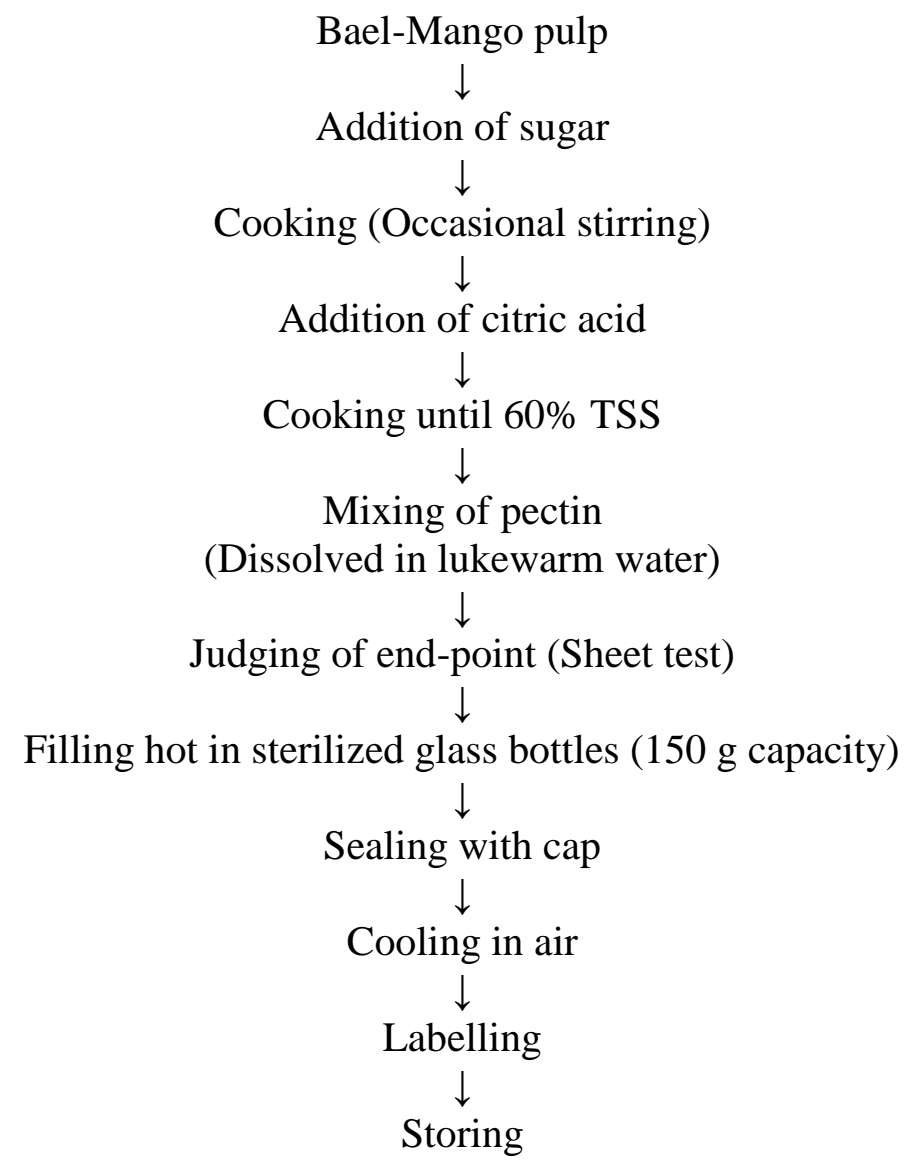

Total carotenoids decreased significantly in bael-mango jam during three months storage period. This might be due to auto-oxidation of $\beta$-carotene leading to loss of total carotenoids and due to its highly unsaturated chemical structure, which made the constituent very susceptible to thermal degradation and oxidation. The results are in accordance with those of Teangpook and Paosantong (2013) in low sucrose lime juice papaya jam. Jam prepared with 0 bael: 100 mango pulp ratio was found most acceptable.

The colour and appearance, texture, taste, flavour, mouthfeel and overall acceptability of bael-mango jam decreased significantly during three months storage period. Similar results were reported by Wani et al., (2013) in karonda jam.

\section{References}

Ranganna, S. (2014). "Handbook of Analysis and Quality Control for Fruit and Vegetable Products" (2 $2^{\text {nd }}$ ed.). Tata McGraw Hills Publishing Co. Ltd., New Delhi.

Rodriguez-Amaya, D.B. (1999). A Guide to Carotenoids Analysis in Foods. p. 63, ILSI Press, Washington.

Safdar, M.N., Mumtaz, A., Hameed, T., Siddiqui, N., Khalil, S. and Amjad, M. (2012). Storage studies of jam prepared from different mango varieties. Pakistan Journal of Nutrition, 11(7), 555-561.

Saravanan, K., Godara, R.K., Goyal, R.K., Sharma, R.K. (2004). Studies on the 
storage behavior of papaya jam. Haryana J. hort. Sci, 33(3\&4), 218-220.

Teangpook, C. and Paosantong, U. (2013).

Production and shelf-life of low sucrose lime juice papaya jam. Pakistan Journal of Nutrition, 12(9), 870-878.
Wani, R.A., Prasad, V.M., Hakeem, S.A., Sheema, S., Angchuk, S. and Dixit, A. (2013). Shelf life of karonda jams (Carissa carandas L.) under ambient temperature. African Journal of Agricultural Research, 8(21), 24472449.

\section{How to cite this article:}

Shafaly Sharma, Rakesh Gehlot, Rattan Singh, Rekha and Ritu Sindhu. 2019. Preparation and Evaluation of Bael-Mango Jam. Int.J.Curr.Microbiol.App.Sci. 8(07): 663-667. doi: https://doi.org/10.20546/ijcmas.2019.807.082 